\title{
EFEKTIVITAS EKSTRAK IKAN GABUS SEBAGAI ANTIHIPERGLIKEMIK
}

\author{
Firinda Soniya*, Milatul Fauziah \\ Fakultas Kedokteran, Universitas Lampung, J1. Prof. Dr. Ir. Sumantri Brojonegoro No.1, Gedong \\ Meneng, Kec. Rajabasa, Kota Bandar Lampung, Lampung, Indonesia 35145 \\ *firindasoniya@gmail.com (+6282280929874)
}

\begin{abstract}
ABSTRAK
Diabetes melitus merupakan penyakit metabolik yang ditandai dengan meningkatkan kadar glukosa darah atau penderita dalam kondisi hiperglikemik. Jumlah penderita diabetes melitus di dunia mengalami peningkatan setiap tahunnya. Laporan WHO pada tahun 2015 menunjukkan 422 juta orang mengalami kondisi diabetes melitus. Indonesia merupakan negara dengan penderita diabetes tertinggi ke-7 di dunia dengan prevalensi kasus pada tahun 2016 sebesar 12.2 juta orang. Ikan gabus (Channa striata) diketahui memiliki kandungan protein yang tinggi dan diketahui dapat dimanfaatkan sebagai sumber antioksidan antihiperglikemik maupun antidiabetes. Kadar protein dalam 100 gram ikan gabus dapat mencapai $25.2 \%$. Terdapat 15 jenis asam amino yang ditemukan pada protein ikan gabus yang meliputi 9 jenis asam amino esensial berupa histidin, treonin, arginin, metionin, valin, fenialanin, leusin, isoleusin, dan lisin. Arginin bekerja dengan meningkatkan fungsi sel beta, meningkatkan pengeluaran energi dan sensitivitas insulin. Sedangkan leusin bekerja dalam transkripsi gen dan sintesis protein pada sel beta pankreas. Kandungan senyawa albumin pada ikan gabus juga dilaporkan memiliki aktivitas antioksidan pada sel beta pankreas.
\end{abstract}

Kata kunci: channa striata, hiperglikemik, diabetes, asam amino

\section{EFFECTIVENESS OF SNAKEHEAD FISH (Channa striata) EXTRACT AS AN ANTI-HYPERGLYCEMIC}

\begin{abstract}
Diabetes mellitus is a metabolic disease characterized by increasing blood glucose levels or hyperglycemic conditions. The number of people with diabetes mellitus in the world has increasing every year. The WHO report in 2015 showing 422 million people had diabetes mellitus. Indonesia is the 7th highest diabetes sufferer in the world with a case prevalence in 2016 of 12.2 million people. Snakehead (Channa striata) has been sources have a high protein content and is known to be used as a source of antihyperglycemic and antidiabetic antioxidants. Protein levels in 100 grams of snakehead fish can reach 25.2\%. There are 15 types of amino acids found in snakehead protein which include 9 types of essential amino acids in the form of histidine, threonine, arginine, methionine, valine, phenialanine, leucine, isoleucine, and lysine. Arginine works by increasing beta cell function, increasing energy expenditure and insulin sensitivity. Whereas leucine works in gene transcription and protein synthesis in pancreatic beta cells. The content of albumin compounds in snakehead fish is also reported to have antioxidant activity on pancreatic beta cells.
\end{abstract}

Keyword: channa striata, hyperglycemic, diabetes, amino acids

\section{PENDAHULUAN}

Diabetes melitus menjadi salah satu penyakit tidak menular dengan angka kematian yang cukup tinggi di dunia.
Selain itu 30\% dari jumlah penderita yang terdiagnosis diabetes merasa telah kehilangan harapan hidupnya. Berdasarkan laporan statistik dari 
International Diabetes Federation, prevalensi penderita diabetes dari total populasi di dunia yaitu sebesar $8.8 \%$ atau 424.9 juta orang di tahun 2017. Angka ini diperkirakan meningkat menjadi $48 \%$ atau 628.6 juta orang pada tahun 2045 (IDF, 2017). Menurut World Health Organization (WHO) pada tahun 2015, penderita diabetes di dunia mencapai 422 juta orang atau sebesar $8.5 \%$ dari jumlah populasi orang di dunia menderita diabetes melitus. Jumlah ini diperkirakan akan meningkat menjadi 642 juta orang di tahun 2040. Sedangkan di Indonesia, penderita diabetes melitus telah mengalami peningkatan dari 5.7\% pada tahun 2007 menjadi $6.9 \%$ pada tahun 2016 atau berjumlah 12.2 juta orang. Pada tahun 2015, Indonesia menjadi negara tertinggi ke-7 di dunia dengan kasus diabetes melitus dan negara tertinggi ke-2 di dunia dengan kematian akibat kasus diabetes melitus (WHO, 2016; Kemenkes, 2013).

Diabetes melitus merupakan penyakit metabolik yang mengharuskan penderitanya untuk mengkonsumsi obat secara teru-menerus. Tentunya kondisi ini akan memberikan efek samping terhadap tubuh serta mempengaruhi psikologi penderita sehingga mendorong penderita untuk mencari pengobatan lain salah satunya dengan menggunakan bahan-bahan alami (Ismarani, 2013). Pengobatan beberapa penyakit metabolik salah satunya diabetes melitus tersebut, sudah banyak memanfaatkan antioksidan dari bahanbahan alami baik yang berasal dari ekstrak nabati maupun ekstrak hewani. Salah satu contoh bahan pangan yang dapat dimanfaatkan sebagai sumber antioksidan untuk pengobatan penyakit diabetes melitus yaitu ikan gabus. Ikan gabus (Channa striata) diketahui memiliki kandungan protein yang sangat tinggi jika dibandingkan dengan jenis ikan tawar lainnya (Aisyatusoffi dan Abdulgani 2013). Kandungan protein yang bertindak sebagai antioksidan pada ikan gabus disebutkan dapat berperan dalam menghambat enzim $\alpha$-glukosidase yang menyebabkan perubahan karbohidrat menjadi glukosa sehingga mampu mengontrol kadar glukosa darah (Prastari C, 2017).

\section{METODE}

Penulisan penelitian ini menggunakan metode literature review. Sumber pustaka yang digunakan berjumlah 14 artikel dan penulis menggabungkan serta menyajikan kembali analisis ilmiah materi sebelumnya dalam bentuk ringkasan yang relevan dengan hasil publikasi sebelumnya tersebut.

\section{HASIL}

Penelitian yang dilakukan oleh Aisyatusoffi dan Abdulgani pada tahun 2013 mengenai pengaruh pemberian ekstrak ikan gabus (Channa striata) pada struktur histologi pankreas dan kadar glukosa darah mencit (Mus musculus) hiperglikemik selama 14 hari menunjukkan bahwa terapi ekstrak ikan gabus $0.148 \mathrm{ml} /$ hari dapat menurunkan kadar glukosa darah sebesar $34.42 \%$.

\section{PEMBAHASAN}

Diabetes melitus adalah penyakit metabolik yang ditandai dengan gejala hiperglikemia sebagai akibat dari gangguan sekresi hormon insulin yang merupakan hormon yang mengatur keseimbangan kadar glukosa darah atau meningkatkan resistensi sel terhadap hormon insulin. Terdapat dua tipe utama diabetes yaitu diabetes tipe 1 dan diabetes tipe 2. Diabetes tipe 1 atau dikenal pula dengan istilah Insulin Dependent Diabetes Mellitus (IDDM) atau Juvenilel Childhood-Onset 
Diabetes, terjadi karena rusaknya sel beta pankreas yang mengakibatkan jumlah sekresi dari hormon insulin berkurang sehingga terganggunya proses pengambilan glukosa dari sirkulasi darah dan berujung pada kegagalan dalam mengontrol kadar glukosa dalam darah. Diabetes tipe 2 atau dikenal pula dengan istilah NonInsulin Dependent Diabetes Mellitus (NIDDM) atau Adult-Onset Diabetes, terjadi karena penggunaan hormon insulin yang kurang efektif oleh tubuh dimana jumlah insulin yang terdapat dalam tubuh jumlahnya cukup akan tetapi insulin tersebut tidak sensitif lagi sehingga tidak mampu bekerja secara optimal dan glukosa yang merupakan sumber energi tubuh menjadi terhambat proses metabolismenya dan berakibat pada sel kekurangan energi (Kemenkes, 2014).

Ikan gabus (Channa striata) merupakan salah satu jenis ikan air tawar yang banyak ditemukan di sungai maupun perairan umum. Ikan gabus memiliki senyawa yang penting bagi tubuh seperti protein dan mineral. Kadar protein dalam 100 gram ikan gabus dapat mencapai $25.2 \%$ dengan kadar albumin yang cukup tinggi yaitu $6.22 \%$ dan mineral berupa $\mathrm{Zn}$ dengan kadar $1.74 \mathrm{mg}$ (Santoso, 2009). Berdasarkan penelitian Prasatari dkk (2017) disebutkan bahwa terdapat 15 jenis asam amino yang ditemukan pada protein ikan gabus yang meliputi 9 jenis asam amino esensial berupa histidin, treonin, arginin, metionin, valin, fenialanin, leusin, isoleusin, dan lisin. Asam amino dapat dikelompokkan menjadi dua kelompok yaitu asam amino yang dapat menstimulasi insulin dan yang tidak dapat menstimulasi insulin. Kelompok asam amino yang dapat menstimulasi insulin terdiri dari leusin, arginin, lisin, alanin, fenilalanin, isoleusin, dan metionin (Karlina, 2012). Mekanisme sekresi insulin yang distimulasi oleh asam amino jenis leusin secara spesifik dapat melalui dua jalur. Pertama, melalui jalur katabolisme leusin menjadi produk akhir asetil-CoA dan asetoasetil CoA sehingga dapat terlibat dalam pembentukan energi melalui siklus TCA; kedua, asam amino leusin mampu mengaktivasi glukokinase sehingga dapat meningkatkan energi melalui glikolisis. Sedangkan asam amino fenilalanin, isoleusin, dan metionin menstimulasi sekresi insulin hanya melalui jalur peningkatan energi pada siklus TCA. Selain itu asam amino jenis alanin juga mampu menstimulasi sekresi insulin melalui dua jalur yaitu melalui sistem co-transport natrium dan jalur siklus TCA (Newsholme, 2007; Kanetro, 2009).

Pada kondisi hiperglikemia, proses penurunan kadar glukosa darah oleh aktivitas ekstrak ikan gabus disebabkan adanya peran dari kandungan senyawa asam amino protein ikan gabus yaitu arginin dan leusin dalam meregulasi kadar glukosa darah. Asam amino menurunkan kadar glukosa serum post prandial tanpa mempengaruhi kadar insulin plasma. Arginin bekerja dengan meningkatkan fungsi sel beta, meningkatkan pengeluaran energi dan sensitivitas insulin. Sedangkan leusin bekerja dalam transkripsi gen dan sintesis protein pada sel beta pankreas. Leusin dapat meningkatkan sekresi insulin dan memperbaiki kontrol glikemik pada penderita dengan kadar glukosa darah tidak terkontrol (Muhtadi \& Suhendi A, 2018; Stantic dkk, 2012). Selain itu pada ikan gabus juga terdapat senyawa albumin yang dilaporkan memiliki aktivitas antioksidan dengan mekanisme kerja multiple-binding sites pada radikal bebas. Antioksidan ini 
kemudian akan menurunkan laju peroksidasi lipid pada sel beta yang rusak dan meregenerasinya (Mustafa dkk, 2012).

\section{SIMPULAN}

Diabetes melitus merupakan penyakit metabolik yang mengharuskan penderitanya meminum obat secara terus-menerus. Ikan gabus (Channa striata) diketahui bertindak sebagai sumber antioksidan yang dapat memberikan efek menurunkan kadar glukosa darah melalui kandungan senyawa berupa asam amino di dalam protein ikan gabus.

\section{DAFTAR PUSTAKA}

Aisyatussoffi N, Abdulgani N. Pengaruh pemberian ekstrak ikan gabus (Channa striata) pada stuktur histologi pankreas dan kadar glukosa darah mencit (Mus musculus) hiperglikemik. Jurnal Sains Dan Seni Pomits. 2(1): 2337- 3520.

International Diabetes Federation (IDF). 2017. Diabetes Atlas 7th Edition: International Diabetes Federation.

Ismarani. 2013. Kajian persepsi konsumen terhadap penggunaan obat herbal (Kasus di Unisma Bekasi). Jurnal Agribisnis Pengembangan. 4(2):53-62.

Kanetro B. 2009. Kajian profil asam amino kecambah kedelai: hubungannya dengan jumlah insulin pancreatic islet tikus normal dan diabetes [disertasi]. Yoyakarta (ID): Universitas Gadjah Mada.

Karnila R. 2012. Daya hipoglikemik protein teripang pasir
(Holothuria scabra J) pada tikus percobaan [disertasi]. Bogor (ID): Institut Pertanian Bogor.

Kemenkes RI. 2014. Pusat Data dan Informasi: Situasi dan Analisis Diabetes. Jakarta.

Kemenkes. 2013. Riset kesehatan dasar. Jakarta : Badan Penelitian dan Pengembangan Kemenkes RI.

Muhtadi M \& Suhendi A. 2018. Aktivitas Antidiabetes dari Kombinasi Serbuk Ikan Gabus (Channa striata) dan Estrak Etanol Kulit Buah Rambutan (Nephelium lappaceum) pada Tikus Putih Jantan Galur Wistar. Jurnal Farmasi Sains dan Praktis. 4(2):9-14.

Mustafa A, Widodo MA, and Kristianto Y. 2012. Albumin And Zinc Content of Snakehead Fish (Channa striata) Extract And Its Role In Health. International Journal of Science and Technology. 1(2):1-8.

Newsholme P, Brennan L, Bender K. 2007. Amino acid metabolism, insulin secretion, and diabetes. Journal Biochemical Society Transactions. $\quad 35:$ 1180-1186.

Prastari C, Yasni S, dan Nurilmala M. 2017. Karakteristik Protein Ikan Gabus yang Berpotensi sebagai Antihiperglikemik. JPHPI. 20(2):413-23.

Santoso H. 2009. Uji potensi ekstrak ikan gabus (Channa striata) sebagai hepatoprotector pada tikus yang diinduksi dengan parasetamol. [tesis]. Bogor (ID): Institut Pertanian Bogor. 
Stancic A., Korac A., Buzadzic B., Otasevic V., Jankovic A., Vucetic M. and Korac B. 2012. L -Arginine in Nutrition : Etiopathology of Diabetes Multiple Beneficial Effects in the Etiopathology of Diabetes. Journal of Nutritional Therapeutics. (2):114-131.

World Health Organization (WHO). 2016. Global Report on Diabetes. 
Jurnal Penelitian Perawat Profesional, Volume 2 No 1 Hal 65 - 70, Februari 2020 Global Health Science Group 